\title{
Trypanosoma vivax nos tecidos testicular e epididimário de ovinos experimentalmente infectados ${ }^{1}$
}

\author{
Francisco Silvestre B. Bezerra², Herakles A. Garcia ${ }^{3}$, Heron M. Alves ${ }^{4}$, Isabelle \\ R.S. Oliveira ${ }^{4}$, Anderson E. Silva ${ }^{4}$, Marta M.G. Teixeira ${ }^{5}$ e Jael S. Batista ${ }^{6^{*}}$
}

\begin{abstract}
Bezerra F.S.B., Garcia H.A., Alves H.M., Oliveira I.R.S., Silva A.E., Teixeira M.M.G. \& Batista J.S. 2008. [Trypanosoma vivax in testicular and epidydimal tissues of experimentally infected sheep.] Trypanosoma vivax nos tecidos testicular e epididimário de ovinos experimentalmente infectados. Pesquisa Veterinária Brasileira 28(12):575-582. Laboratório de Patologia Veterinária, Departamento de Ciências Animais, Universidade Federal Rural do Semi-árido, BR 110 Km 47, Cx. Postal 147, Mossoró, RN 59625-900, Brazil. E-mail: jaelsbatista@hotmail.com

Four adult sheep (number 1, 2, 3 and 4), all males, were inoculated intravenously with $1 \mathrm{ml}$ of blood containing $1.25 \times 10^{5}$ trypomastigotes of Trypanosoma vivax, and Sheep 5, 6, 7 and 8 were used as control. After infection, clinical exams considering rectal temperature, respiratory and cardiac frequencies, and parasitaemia were recorded daily for a 30-day experiment period. Blood samples were obtained for 5-day intervals to hematocrit analysis. At the end of the experimental period, the sheep were orquiectomized. Testes and epididymides from these animals were studied anatomopathologically. Samples from these tissues of Sheep 1, 4 and 5 were taken to polymerase chain reaction (PCR). Clinical parameters remained for the infected group above the values observed in the control group during the experimental period. Parasitaemia was observed on day 3 post-infection, and the highest values occurred between day 6 and 10, and day 15 and 18 post-infection. Sheep 1 and 4 showed severe anemia on day 25 post-infection. All sheep of the infected group showed flabby and palid testes. Histologically, moderate to severe testicular degeneration, multifocal epididymitis and hyperplasia of epididymal epithelium were observed. The result of $T$. vivax PCR analysis in the testes and epididymal tissues was positive in $100 \%$ of the samples of the experimentally infected sheep. Epididymal and testicular lesions associated with the presence of the parasite in these tissues, shown by PCR, suggest the participation of $T$. vivax in the pathophysiological mechanism of reproductive damage.
\end{abstract}

INDEX TERMS: Trypanosomosis, small ruminant, PCR, anatomopathology, testicular degeneration, epididymitis, extravascular foci.

\footnotetext{
${ }^{1}$ Recebido em 9 de junho de 2008.

Aceito para publicação em 23 de junho de 2008.

2 Programa de Mestrado em Ciência Animal, Universidade Federal Rural do Semi-árido (UFERSA), BR110 Km 47, Bairro Presidente Costa e Silva, Mossoró, RN 59625-900, Brasil.

${ }^{3}$ Programa de Doutorado em Biologia da Relação Patógeno-Hospedeiro, Instituto de Ciências Biomédicas (ICB), Universidade de São Paulo (USP), Av. Professor Lineu Prestes 1374, Cidade Universitária, São Paulo, SP 05508-000, Brasil.
}

\footnotetext{
${ }^{4}$ Graduando em Medicina Veterinária, Laboratório de Patologia Veterinária, Departamento de Ciências Animais, UFERSA, Mossoró, RN 59625-900.

${ }^{5}$ Departamento de Parasitologia, ICB, USP, Av. Professor Lineu Prestes 1374, Cidade Universitária, São Paulo, SP 05508-000, Brasil.

${ }^{6}$ Laboratório de Patologia Veterinária, Departamento de Ciências Animais, UFERSA, Mossoró, RN 59625-900. *Autor para correspondência: jaelsbatista@hotmail.com
} 
RESUMO.- Quatro ovinos machos, com cerca de 12 meses de idade (Ovinos 1-4), foram infectados por via intravenosa com aproximadamente $1,25 \times 10^{5}$ tripomastigotas de Trypanosoma vivax, outros quatro ovinos (Ovinos 5-8) destinaram-se ao grupo controle. Após a infecção, exames clínicos visando avaliar temperatura retal, freqüências cardíaca e respiratória e parasitemia foram realizados diariamente por 30 dias, tempo estabelecido para o término do experimento. A avaliação do hematócrito foi realizada a cada cinco dias. Ao final do período experimental, os animais foram castrados e os testículos e epidídimos submetidos ao exame anatomopatológico. Amostras destes órgãos dos Ovinos 1, 4 e 5 foram tomadas para a realização da reação em cadeia da polimerase (PCR). Os parâmetros clínicos (hipertermia, aumento das freqüências cardíaca e respiratória, aumento de volume dos linfonodos e palidez das mucosas) mantiveram-se para o grupo infectado acima dos valores mostrados pelo grupo controle durante todo o período experimental. A parasitemia foi observada a partir do $3^{\circ}$ dia pós-infecção (dpi) com picos nos 6-10 $0^{\text {os }} \mathrm{dpi}$ e nos $15-18^{\text {os }} \mathrm{dpi}$. Os Ovinos 1 e 4 apresentaram, a partir do $25^{\circ} \mathrm{dpi}$, anemia acentuada. Macroscopicamente, todos os testículos dos animais do grupo infectado apresentaram-se flácidos e com coloração pálida. Microscopicamente, observaram-se degeneração testicular moderada a acentuada, epididimite multifocal e hiperplasia do epitélio epididimário. A análise por PCR de T. vivax nos tecidos testicular e epididimário resultou em $100 \%$ de positividade para ovinos infectados experimentalmente. As lesões epididimárias e testiculares associadas à presença do parasita nesses órgãos, detectada por PCR, sugerem a participação do parasita no mecanismo etiopatogênico de danos reprodutivos.

TERMOS DE INDEXAÇÃO: Tripanossomíase, pequeno ruminante, PCR, anatomopatologia, degeneração testicular, epididimite, sítio extravascular.

\section{INTRODUÇÃO}

As tripanossomíases possuem grande relevância econômica para a pecuária por gerarem perdas na produção de leite, infertilidade, aborto, orquite, anemia e morte dos animais afetados (Losos 1986, Anosa 1988). Dentre os tripanossomas mais patogênicos para animais domésticos estão Trypanosoma congolense, $T$. vivax e $T$. brucei (Anosa 1988). A tripanossomíase por T. vivax já foi reportada em muitos países da América Latina (Dávila \& Silva 2000), e, dentre estes está o Brasil, onde foi registrada em alguns estados. O primeiro relato ocorreu em búfalos no estado do Pará (Shaw \& Lainson 1972), seguido por outros descritos em bovinos nos estados do Mato Grosso (Silva et al. 1996), Mato Grosso do Sul (Paiva et al. 2000), Tocantins (Linhares et al. 2006) e Paraíba (Batista et al. 2007).

Em fêmeas bovinas infectadas naturalmente por $T$. vivax, várias desordens reprodutivas já foram reportadas. Aborto, repetição de cio, natimortos ou nascimento de crias fracas e anestro temporário ou permanente são as alterações mais freqüentemente relatadas (Silva et al. 2004, Bezerra et al. 2006, Batista et al. 2007, 2008).

Em machos, patologias reprodutivas ocasionadas por T. vivax estão especialmente ligadas a lesões do testículo e epidídimo. Nos casos crônicos, infertilidade ou mesmo esterilidade estão presentes (Sekoni et al. 1990, Adamu et al. 2007). Sekoni et al. (2004) relataram alterações como queda na qualidade do sêmen de zebus infectados por T. vivax, manifestada por uma drástica redução da concentração espermática (oligospermia ou mesmo azoospermia), diminuição do volume do sêmen, bem como aumento das anormalidades morfológicas espermáticas. Adamu et al. (2007) realizaram infecção experimental em zebuínos com $T$. vivax e constataram que os danos ao testículo e ao epidídimo são progressivos, agravando-se com o decorrer da infecção. Os autores descreveram uma drástica redução do número de células espermatogênicas, destruição do tecido intersticial com túbulos seminíferos hipoplásicos, desaparecimento das células de sertoli e comprometimento do parênquima epididimário com áreas de necrose e depleção da reserva espermática.

Embora o sítio de multiplicação de $T$. vivax seja exclusivamente extracelular, na corrente circulatória, ocasionalmente, o período septicêmico é seguido pela migração extravascular do parasita (Gardiner 1989). Tal fato tem grande importância na fisiopatogenia das lesões inflamatórias e degenerativas descritas no coração (Masake 1980) e sistema nervoso (Whitelaw et al. 1988) de caprinos infectados experimentalmente por $T$. vivax.

$T$. vivax já foi identificado no sistema nervoso central, humor vítreo (Whitelaw et al. 1988) e miocárdio (Kimeto et al. 1990) onde foi apontado como causador de patologias nessas regiões. Entretanto, ainda não se encontrou relatos da presença do parasita no parênquima de órgãos reprodutivos.

Apesar da descrição das lesões histopatológicas em testículos e epidídimos de ruminantes infectados com $T$. vivax, dados que elucidem a patogênese das lesões são escassos. Desta forma, o objetivo deste trabalho consistiu em descrever as lesões anatomopatológicas em testículos e epidídimos de ovinos infectados experimentalmente por $T$. vivax, bem como pesquisar através da reação em cadeia da polimerase (PCR) a presença do DNA do parasita nesses tecidos, visando estabelecer uma associação entre a presença do parasita no tecido com a severidade das lesões.

\section{MATERIAL E MÉTODOS}

\section{Composição dos grupos experimentais}

Oito ovinos machos sem raça definida, com cerca de 12 meses de idade, foram utilizados para a composição dos grupos experimentais e acomodados em baias do Hospital Veterinário da Universidade Federal Rural do Semi-árido (UFERSA). Por 14 dias antes da inoculação do Trypanosoma vivax, os ovinos foram avaliados através de exames clínicos e hematológicos e dosificados com anti-helmínticos. Os animais foram divididos 
aleatoriamente em dois grupos experimentais: o grupo infectado, constituído por quatro ovinos infectados por T. vivax (Ovinos 1, 2, 3 e 4); grupo controle, composto quatro por ovinos não infectados por T. vivax (Ovinos 5, 6, 7 e 8).

Todos os animais correspondentes aos citados grupos foram submetidos a condições de manejo idênticas, alimentados com água à vontade, feno de capim tifton e ainda suplementados com ração comercial na quantidade de $1,5 \%$ de peso do animal por dia.

\section{Preparo do inóculo e infecção experimental com Trypano- soma vivax}

A cepa de T. vivax utilizada no presente estudo foi coletada de um bovino parasitêmico durante surto relatado por Batista et al. (2008) no município de Catolé do Rocha-PB. O sangue foi acondicionado em tubos contendo EDTA a $10 \%$ e, em seguida, misturado a $8 \%$ de glicerol para a criopreservação em nitrogênio líquido. Imediatamente antes da inoculação foi realizado o descongelamento da cepa de acordo com metodologia descrita por Silva et al. (2002). Em cada animal do grupo infectado, inoculou-se intravenosamente $1 \mathrm{ml}$ de sangue contendo aproximadamente $1,25 \times 10^{5}$ tripomastigotas de $T$. vivax, estimados de acordo com o método de Brener (1961).

\section{Exames clínicos e determinação da parasitemia}

Nos ovinos dos grupos infectado e controle foram realizados diariamente por 30 dias, ao final da tarde, a determinação da parasitemia de acordo com o método de Brener (1961), bem como exames clínicos para avaliar a temperatura retal, freqüências cardíaca e respiratória, aspecto das mucosas aparentes e volume dos linfonodos externos à palpação, assim como o comportamento e o estado geral.

\section{Avaliação do hematócrito}

Através da punção da veia jugular, coletou-se $2 \mathrm{ml}$ de sangue de cada animal dos grupos experimental e controle, que foram acondicionados em tubos contendo $1 \mathrm{mg} / \mathrm{ml}$ de sangue para a realização do hematócrito. As coletas ocorreram um dia antes e a cada cinco dias após a infecção durante 30 dias. O volume globular ou hematócrito foi obtido pela técnica do microhematócrito (Ferreira Neto et al. 1981).

\section{Exame anatomo-histopatológico dos testículos e epidídimos}

Trinta dias após a infecção experimental com T. vivax, os ovinos pertencentes a cada grupo foram orquiectomizados pelo método cirúrgico. Avaliação macroscópica dos testículos e epidídimos foi realizada e estes foram fixados em solução de Bouin por 48 horas. Em seguida, foram conservados em álcool etílico a $70 \%$. Após fixação, os testículos foram seccionados na porção média, enquanto os epidídimos foram seccionados na região da cauda. A seguir, os tecidos foram incluídos em parafina, cortados a uma espessura de 5 mícrons e corados pela Hematoxilina e Eosina. As lâminas histológicas foram avaliadas por microscopia óptica, onde as alterações histopatológicas testiculares foram classificadas em graus de degeneração testicular, tal como descrito por Rio Tinto et al. (2004), enquanto no epidídimo foi identificada a presença ou ausência de alterações inflamatórias.

\section{Diagnóstico por PCR no testículo e epidídimo}

Fragmentos de aproximadamente $1 \mathrm{~cm}$ dos antímeros direito e esquerdo de testículos e epidídimos dos Ovinos 1, 4 e 5, escolhidos aleatoriamente, foram coletados e acondicionados em microtubos Eppendorf contendo álcool a 70\% para a pesquisa do parasita nos tecidos através da realização do exame de reação em cadeia da polimerase (PCR).

As amostras foram processadas para a extração do DNA através da digestão dos tecidos testicular e epididimário. Fragmentos internos dos tecidos foram cortados com bisturi estéril, lavados exaustivamente em água destilada e digeridos em tampão de lise (1\% SDS, $100 \mathrm{mM}$ de EDTA pH 8.0, 20mM de Tris- $\mathrm{HCl} \mathrm{pH} 8.0$ e $350 \mathrm{mg} / \mathrm{ml}$ de proteinase $\mathrm{K}$ ) a $37^{\circ} \mathrm{C}$ por 18 horas. As amostras foram centrifugadas a $17.530 \mathrm{~g}$ durante 10 minutos. Uma alíquota de $300 \mathrm{ml}$ do sobrenadante foi processada utilizando-se colunas de purificação de DNA (Wizard® DNA Clean-Up System, Promega) de acordo com as especificações do fabricante. Oito ml de DNA foram usados como alvo nas PCRs. Foram avaliadas reações preliminares de amplificação empregando como alvo quantidades crescentes de DNA $(2,4,6$, $8,10 \mathrm{ml}$ ), as quais mostraram que entre 6 e $8 \mathrm{ml}$ do material alvo geravam uma ótima amplificação do fragmento esperado.

A PCR foi usada para amplificar uma região de $177 \mathrm{pb}$ (pares de bases) no domínio catalítico do gene da Catepsina L, específica para $T$. vivax e conservada entre diferentes amostras do parasita, através dos primers Tvi2 (forward: 5' GCC ATC GCC AAG TAC CTC GCC GA 3') e DTO156 (reverse: 5' TTAGAATTCCCAGGAGTTCTTGATGATCCAGTA 3'). As PCRs foram realizadas com um volume final de $50 \mathrm{ml}$ contendo $2.5 \mathrm{U}$ de Taq DNA polimerase, $0.2 \mathrm{mM}$ de cada dNTP, $100 \mathrm{ng}$ de cada primer, $1,5 \mathrm{mM} \mathrm{MgCL}$. Os parâmetros estabelecidos para os ciclos foram: uma desnaturação a 94ํㅡ por 3 minutos seguidos de 39 ciclos de amplificação com fases de: desnaturação (94. $\mathrm{C}$ por $1 \mathrm{~min}$.), anelamento $\left(62^{\circ} \mathrm{C}\right.$ por $1 \mathrm{~min}$.), e extensão $\left(72^{\circ} \mathrm{C}\right.$ por $1 \mathrm{~min}$.), além de uma extensão final de $72^{\circ} \mathrm{C}$ por $10 \mathrm{mi}-$ nutos.

Uma alíquota de $25 z$ l de cada amostra amplificada foi examinada em gel de agarose a 2,0\%, corado com Brometo de Etídio e fotografado usando um sistema de documentação de gel sob luz ultra-violeta. Empregou-se como marcador do peso molecular 100pb DNA-ladder.

\section{Análise estatística}

Para a análise das variações dos dados das freqüências cardíaca e respiratória e temperatura retal foi utilizado o delineamento inteiramente casualizado e realizada análise de variância, utilizando-se o teste de Tukey do pacote estatístico SAS (1999) para comparação múltiplas das médias ao nível de $5 \%$ de probabilidade, considerando-se como parcelas os grupos infectado e controle, e como subparcela o tempo de infecção. O mesmo teste foi utilizado para análise das variações das médias dos escores estabelecidos para as alterações histopatológicas testiculares e epididimárias entre os grupos e entre as gônadas direita e esquerda.

\section{RESULTADOS}

\section{Exames clínicos e determinação da parasitemia}

Durante o período pré-experimental, não se observaram alterações clínicas ou hematológicas. Os ovinos infectados experimentalmente por Trypanosoma vivax apresentaram hipertermia no 4ํ dia pós-infecção (dpi), com valor máximo $41,3^{\circ} \mathrm{C}$. Os valores médios deste parâmetro apresentaram-se acima dos valores médios do grupo controle até o final do período experimental (Fig.1). 


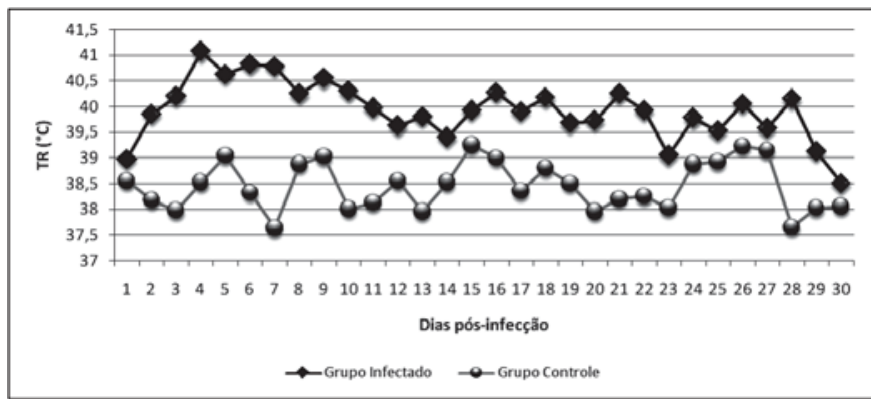

Fig.1. Valores médios das temperaturas retais (TR) em ${ }^{\circ} \mathrm{C}$ em ovinos do grupo experimentalmente infectado por Trypanosoma vivax e do grupo controle durante o período experimental.

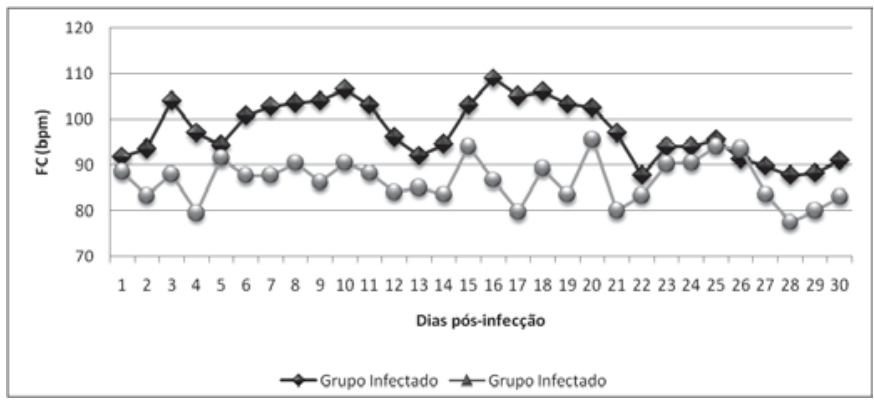

Fig.2. Valores médios das freqüências cardíacas (FC) em batimentos por minuto (bpm) de ovinos do grupo experimentalmente infectados por $T$. vivax e do grupo controle durante o período experimental.

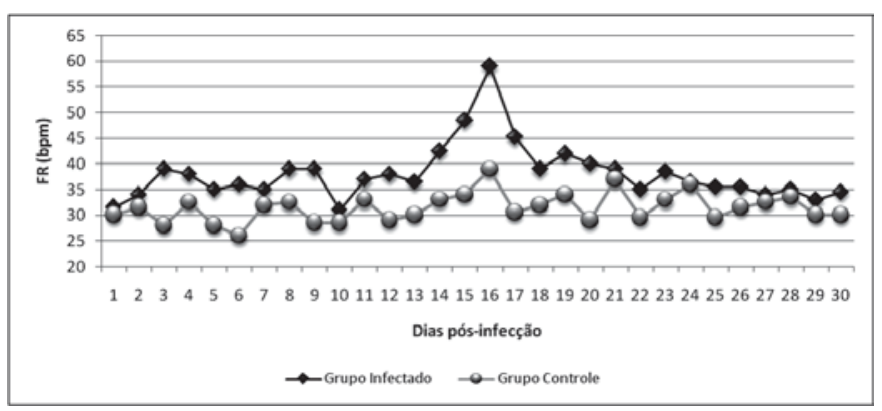

Fig.3. Valores médios das freqüências respiratórias (FR) em movimentos por minuto (mpm) de ovinos do grupo experimentalmente infectados por $T$. vivax e do grupo controle durante o período experimental.

Os maiores valores médios da freqüência cardíaca e diferença significativa em relação ao grupo controle $(P<0,05)$ foram verificados nos seguintes períodos: entre $02^{\circ}$ e $3^{\circ}$ dpi; entre o $9^{\circ}$ e $11^{\circ}$ dpi e entre o $15^{\circ}$ e o $20^{\circ}$ dpi (Fig.2). Quanto à freqüência respiratória, os maiores valores médios e diferença significativa em relação ao grupo controle $(\mathrm{P}<0,05)$ foram observados entre o 14ํㅜ e o $20^{\circ}$ dpi (Fig.3).

Todos os ovinos do grupo infectado apresentaram, do $20^{\circ}$ dpi até o final do período experimental, mucosas pálidas e aumento de volume de todos os linfonodos palpáveis. O Ovino 3 apresentou ainda apatia, opacidade de córnea e secreção ocular bilateral purulenta.

A presença de tripanossomos no sangue periférico foi

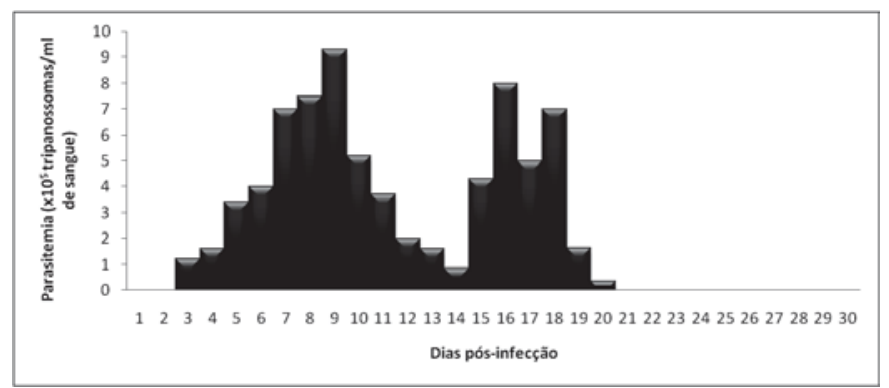

Fig.4. Valores médios das parasitemias ( $\times 10^{5}$ tripanossomas/ $\mathrm{ml}$ de sangue) de ovinos do grupo experimentalmente infectados por $T$. vivax durante o período experimental.

constatada em todos os animais do grupo infectado a partir do $3^{\circ}$ dpi. Os maiores picos parasitêmicos foram obser-

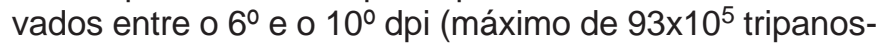
somos/ml de sangue). A partir desse período a parasitemia apresentou valores decrescentes com novo pico entre $15^{\circ}$ e $18^{\circ} \mathrm{dpi}$, seguindo-se a uma nova queda entre 0 $19^{\circ}$ e $20^{\circ} \mathrm{dpi}$. Do $21^{\circ} \mathrm{dpi}$ até o final do período experimental todos os animais apresentaram-se aparasitêmicos (Fig.4).

\section{Avaliação do hematócrito}

Os valores do hematócrito nos animais do grupo controle permaneceram dentro da normalidade para a espécie durante o período experimental. No grupo infectado experimentalmente, apenas os Ovinos 1 e 4 apresentaram no $25^{\circ}$ dpi quadro de anemia com valores do hematócrito avaliados em $22 \%$ e $13 \%$, respectivamente.

\section{Exame anatomo-histopatológico dos testículos e epidídimos}

Os testículos direito e esquerdo de todos os ovinos do grupo infectado apresentaram, macroscopicamente, consistência flácida e coloração pálida. Quanto às alterações histopatológicas, os Ovinos 1, 2 e 3 apresentaram, nos testículos direito e esquerdo, degeneração moderada caracterizada pela redução de células da linhagem

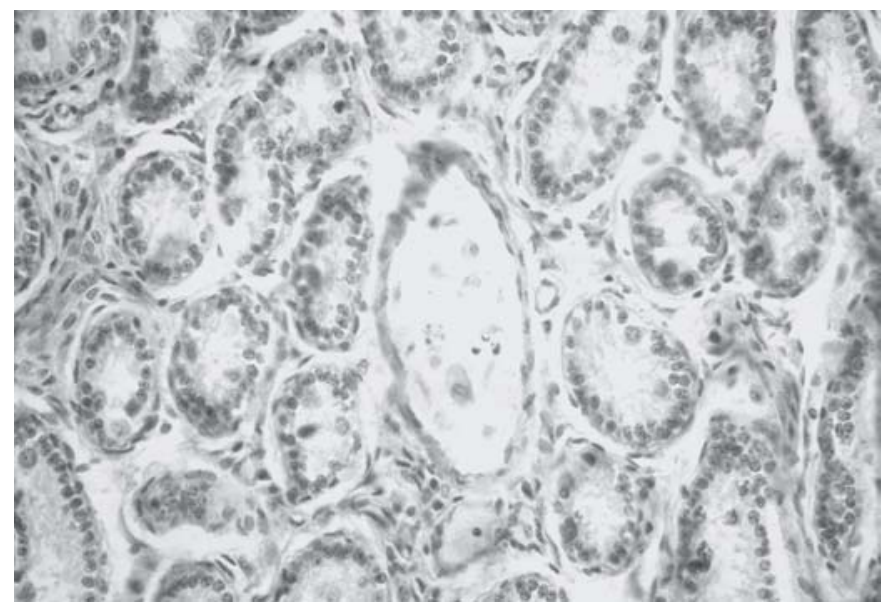

Fig.5. Degeneração testicular acentuada em ovino infectado experimentalmente por T. vivax. HE, obj. 40 . 


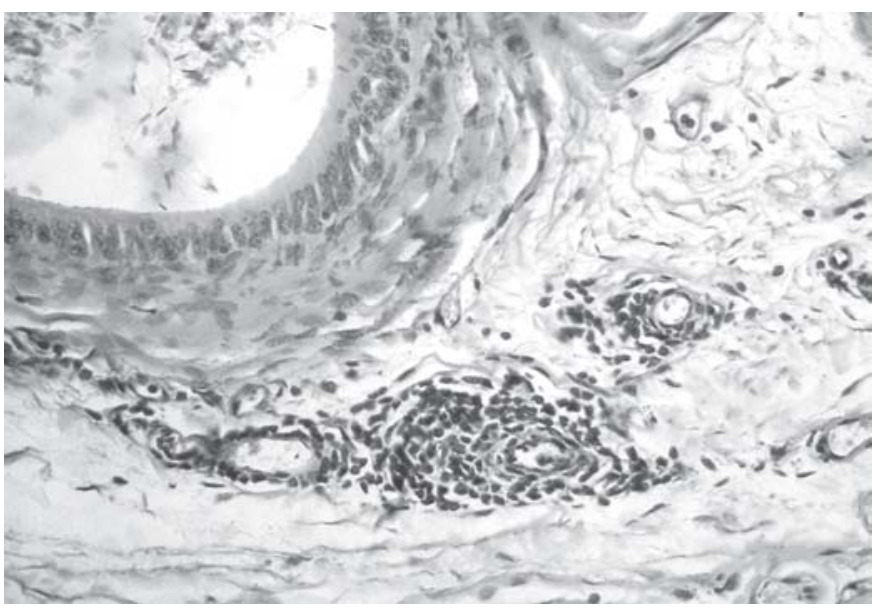

Fig.6. Epididimite perivascular intersticial em ovino infectado experimentalmente por T. vivax. HE, obj.40x.

germinativa e diminuição da altura do epitélio seminífero. As espermatogônias remanescentes apresentaram-se vacuolizadas, com citoplasma granuloso e núcleos em picnose ou em cariorrexe. Em alguns túbulos foi observada a presença de células gigantes multinucleadas. O Ovino 4 apresentou degeneração testicular acentuada com

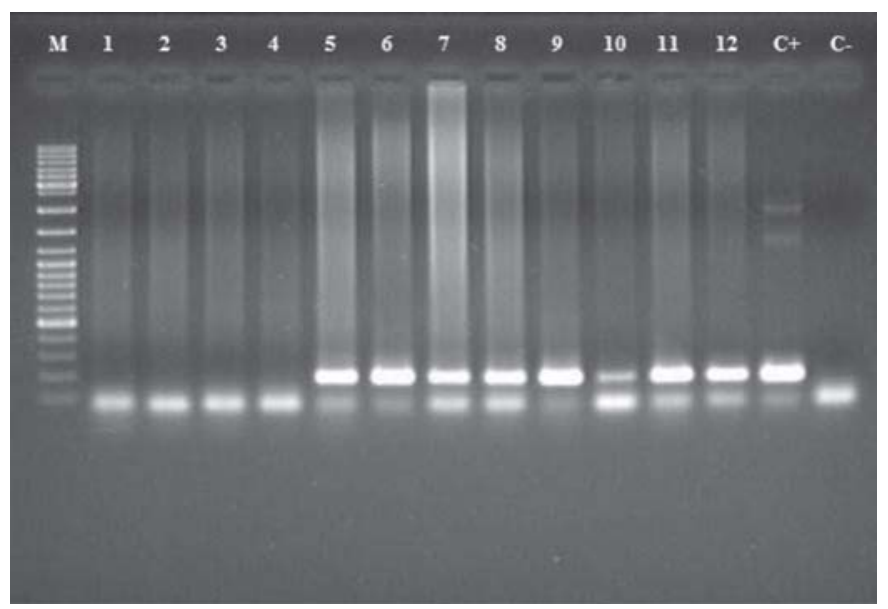

Fig.7. PCR para detecção de T. vivax nos tecidos testicular e epididimário, ultilizando-se $8 z$ l de DNA. Fragmento de $177 \mathrm{pb}$ do gene Catepsina L, específico para $T$. vivax está evidenciado pela seta. $\mathrm{M}=$ marcador molecular; 1 = testículo esquerdo Ovino $5 ; 2$ = epidídimo direito Ovino $5 ; 3=$ testículo direito Ovino 5; 4 = epidídimo esquerdo Ovino 5; 5 = testículo esquerdo Ovino $1 ; 6$ = epidídimo direito Ovino $1 ; 7=$ testículo direito Ovino $1 ; 8=$ epidídimo esquerdo Ovino $1 ; 9=$ testículo esquerdo Ovino 4;10 = epidídimo direito Ovino 4; 11 = testículo direito Ovino 4; 12 = epidídimo esquerdo Ovino 4 ; $\mathrm{C}_{+}=$Controle positivo; $\mathrm{C}-$ = Controle negativo

\begin{tabular}{|c|c|c|c|c|c|c|}
\hline \multirow{3}{*}{$\begin{array}{l}\text { Ovino } \\
\text { no. }\end{array}$} & \multicolumn{6}{|c|}{ Alterações Histopatológicas } \\
\hline & \multicolumn{2}{|c|}{ Degeneração testicular } & \multicolumn{2}{|c|}{ Epididimite } & \multicolumn{2}{|c|}{ Hiperplasia epididimária } \\
\hline & $\begin{array}{l}\text { Testículo } \\
\text { Esquerdo }\end{array}$ & $\begin{array}{l}\text { Testículo } \\
\text { Direito }\end{array}$ & $\begin{array}{l}\text { Epidídimo } \\
\text { Esquerdo }\end{array}$ & $\begin{array}{l}\text { Epidídimo } \\
\text { Direito }\end{array}$ & $\begin{array}{l}\text { Epidídimo } \\
\text { Esquerdo }\end{array}$ & $\begin{array}{c}\text { Epidídimo } \\
\text { Direito }\end{array}$ \\
\hline $1 \mathrm{a}$ & Moderada & Moderada & Ausente & Ausente & Ausente & Ausente \\
\hline $2 a$ & Moderada & Moderada & Ausente & Ausente & Ausente & Ausente \\
\hline $3 a$ & Moderada & Moderada & Ausente & Ausente & Ausente & Ausente \\
\hline $4 a$ & Severa & Severa & Presente & Presente & Presente & Presente \\
\hline $5 b$ & SDc & SD & Ausente & Ausente & Ausente & Ausente \\
\hline $6 b$ & $\mathrm{SD}$ & SD & Ausente & Ausente & Ausente & Ausente \\
\hline $7 \mathrm{~b}$ & SD & SD & Ausente & Ausente & Ausente & Ausente \\
\hline $8 \mathrm{~b}$ & SD & SD & Ausente & Ausente & Ausente & Ausente \\
\hline
\end{tabular}

$a=$ Grupo infectado, $b=$ Grupo Controle, $c=$ Sem degeneração.

áreas de ausência do epitélio seminífero e membrana basal espessada (Fig.5). Nesse animal observou-se ainda epididimite multifocal caracterizada por infiltrado de linfócitos e plasmócitos ao redor dos vasos do interstício (Fig.6), bem como uma hiperplasia epitelial. Para todas as alterações histopatológicas avaliadas, não houve diferença significativa $(P>0,05)$ entre as gônadas direita e esquerda. Os animais do grupo controle apresentaram achados histológicos dentro dos parâmetros de normalidade (Quadro 1).

\section{Diagnóstico por PCR no testículo e epidídimo}

Todas as amostras de testículo e epidídimo dos Ovinos 1 e 4, pertencentes ao grupo infectado, revelaram-se positivas para $T$. vivax, enquanto as amostras do Ovino 5 do grupo controle evidenciaram-se negativas na reação em cadeia da polimerase, PCR (Fig.7). Fragmentos compatíveis em número de pares de base (pb) com a seqüência a ser amplificada (fragmento de 177 pb do gene Catepsina L, específico para T. vivax), foram visualizados em gel de agarose a $2 \%$. Deste modo, a análise por PCR do T. vivax nos tecidos testicular e epididimário resultou em $100 \%$ de positividade para ovinos infectados experimentalmente.

\section{DISCUSSÃO}

Para conhecimento do efeito da infecção por Trypanosoma vivax na reprodução, de machos e fêmeas, é necessário, além da avaliação da enfermidade em animais portadores da infecção natural, estudo mediante a infecção experimental. Assim, devido à susceptibilidade de ovinos à tripanossomíase por T. vivax, essa espécie é freqüentemente utilizada para a obtenção de conhecimentos dos 
aspectos fundamentais das manifestações clínicas e patológicas da infecção (Anosa 1983).

As alterações clínicas observadas no presente estudo caracterizadas por altas parasitemias e temperaturas retais, aumentos das freqüências cardíaca e respiratória e alterações oculares confirmam a patogenicidade da cepa de $T$. vivax isolada do sangue de bovinos durante um surto de infecção natural no município de Catolé do Rocha, PB.

Surtos de infecção natural por $T$. vivax foram relatados recentemente em bovinos leiteiros no sertão da Paraíba caracterizados por altas parasitemias, febre, anorexia, aumento das freqüências cardíacas e respiratória, cegueira transitória, acentuada redução da produção leiteira e alterações reprodutivas como abortamento, repetição de cio e anestro (Bezerra et al. 2006, Batista et al. 2007, 2008).

Os eritrogramas dos Ovinos 1 e 4 revelaram acentuada queda no valor do hematócrito, indicando que os animais desenvolveram intensa anemia. A ocorrência da anemia confirma os resultados de trabalhos que relatam essa alteração hematológica como a mais freqüentemente observada em animais infectados naturalmente ou experimentalmente por T. vivax (Pellín et al. 2003, Valera et al. 2005, Batista et al. 2006). A anemia provocada por $T$. vivax é considerada multifatorial, sendo atribuída à hemólise intra e extravascular, diminuição ou inibição da eritropoiese e hemorragias (Holmes 1987).

Nascimento \& Santos (2003) afirmam que as causas de degeneração testicular estão relacionadas a processos patológicos generalizados, e assim, $T$. vivax pode ser causador de degeneração testicular moderada a acentuada como verificado no presente estudo. Muitos agentes infecciosos podem causar lesões escrotais, epididimárias e/ou testiculares em carneiros, como Actinobacillus seminis, A. actinomycetemcomitans, Haemophilus somnus, Corynebacterium pseudotuberculosis, C. pyogenes, Pasteurella spp., Streptococcus spp., Staphylococcus spp. e Brucella ovis (Walker et al. 1986, Robles et al. 1990, Manterola et al. 2003, Clementino et al. 2007), o que pode causar confusão no diagnóstico clínico de alterações testiculares e epididimárias desta espécie. T. vivax, portanto, demonstrou-se ser mais uma opção para diagnóstico diferencial em áreas endêmicas para a doença.

Em touros, T. vivax produz lesões de vários graus no sistema reprodutor, especialmente no testículo e epidídimo (Sekoni et al. 1990, Adamu et al. 2007). As lesões observadas no presente trabalho, em ovinos ao $30^{\circ}$ dia pósinfecção (dpi), demonstram o potencial do patogênico sobre testículo e epidídimo da cepa de $T$. vivax isolada de bovinos naturalmente infectados em Catolé do Rocha, PB. Adamu et al. (2007), ao estudarem alterações histopatológicas testiculares e epididimárias em bovinos infectados experimentalmente por $T$. vivax, também verificaram lesões testiculares e epididimárias caracterizadas por depleção das células espermatogênicas e destruição do tecido intersticial (túbulos seminíferos hipoplásicos além do desaparecimento das células de Sertoli). No epidídimo, os danos chegaram a $60 \%$ de comprometimento do parênquima. Áreas focais de necrose e metaplasia escamosa do epitélio epididimário, com reserva espermática avaliada em $0 \%$ aos $56^{\circ}$ dpi também foram observadas.

A ocorrência de epididimite observada no presente estudo pode constituir mais um indicador histopatológico de danos nos órgãos reprodutivos provocados por $T$. vivax. O quadro histopatológico de epididimite e hiperplasia do epitélio epididimário foi semelhante ao descrito por Dibarrat et al. (2006) em ovinos infectados experimentalmente por Actinobacillus seminis. De acordo com Gomes (1991) os prejuízos econômicos da epididimite em carneiros são causados principalmente por interferirem sobre a fertilidade de machos infectados, especialmente os animais geneticamente superiores e sobre a fertilidade de rebanhos ovinos servidos por esses machos. Entretanto esses efeitos não são perceptíveis e nem mensurados especialmente em criações extensivas.

Outras tripanossomíases também são responsáveis por acarretarem lesões no testículo e epidídimo. CabrineSantos et al. (2003) relataram orquite, retardo da maturação de células germinativas, oligozoospermia e azoospermia no testículo de hamsters infectados experimentalmente por $T$. cruzi. No epidídimo observou-se epididimite, contração tubular, ausência de espermatozóides, e células de descamação. Na fase crônica, formas amastigotas de $T$. cruzi foram encontradas no sistema genital de hamsters, principalmente no testículo (CabrineSantos 2000). Ngeranwa et al. (1991) estudaram os efeitos da infecção experimental com $T$. evansi sobre a fertilidade de carneiros que apresentaram orquite, deterioração da qualidade e quantidade espermática e ainda, na fase crônica, atrofia dos testículos. Histologicamente, detectou-se a presença de microtrombos nos vasos testiculares e infiltração de células inflamatórias. Outro achado relatado pelos autores foi a presença de depósitos de cálcio nos ductos seminíferos e epididimários. T. brucei (Anosa \& Kaneko 1984) e T. congolense (Sekoni et al. 1990, 2004) também foram descritos como causadores de lesões no sistema genital masculino de animais.

A técnica de reação em cadeia da polimerase, PCR, é uma técnica sensível e específica na detecção de animais infectados por $T$. vivax, utilizando-se como material de análise o sangue (Ventura et al. 2001). Entretanto, a técnica de extração de DNA de T. vivax de tecidos para posterior realização da PCR consiste em um fato inédito. O parasita ainda não havia sido identificado no parênquima de órgãos reprodutivos. Desta forma, tais dados assumem importância valiosa para explicar a patogênese das lesões testiculares e epididimárias ocasionadas pelo parasita. No presente estudo, destaca-se a associação entre o parasita em localização testicular e epididimária e a presença de lesões histopatológicas e macroscópicas.

Os mecanismos etiopatogênicos envolvidos na indução de lesões reprodutivas não estão ainda bem entendidos. A possibilidade de que danos na hipófise causados pela 
tripanossomíase podem resultar em disfunção testicular devido a uma interrupção na secreção de LH ou FSH (Apted 1970, Ikede \& Losos 1975) foi refutada por Boly et al. (1994) e Mutayoba et al. (1994) que comprovaram que a função da hipófise não é afetada na enfermidade. Entretanto, muitos mecanismos podem estar envolvidos no desenvolvimento de danos testiculares e epididimários em ovinos experimentalmente infectados como hipertermia, anemia e anorexia (McEntee 1990, Setchell 1998). O testículo é extremamente sensível a aumentos de temperatura e de acordo com Friedman et al. (1991), períodos de insulação testicular de apenas 48h produzem degeneração testicular. Assim, a hipertermia observada em todos os ovinos do grupo infectado pode ter favorecido a ocorrência do processo degenerativo no testículo. Além disso, há a possibilidade de o próprio parasita, detectado por PCR nos órgãos reprodutivos, poder ser causador direto da lesão sobre os tecidos, tal como observado na doença de Chagas humana, através do T. cruzi.

Destarte, a identificação de Trypanosoma vivax através da reação em cadeia da polimerase (PCR) em 100\% das amostras testadas de testículos e epidídimos de animais experimentalmente infectados, associada a lesões como degeneração testicular acentuada a moderada, epididimite e hiperplasia epitelial epididimária nos mesmos animais, permitem concluir que o parasita pode estar envolvido no mecanismo etiopatogênico das lesões.

\section{REFERÊNCIAS}

Adamu S., Fatihu M.Y., Useh N.M., Mamman M., Sekoni V.O. \& Esievo K.A.N. 2007. Sequential testicular and epididymal damage in Zebu bulls experimentally infected with Trypanosoma vivax. Vet. 43:29-34.

Anosa V.O. 1983. Diseases produced by Trypanosoma vivax infection in ruminants, horses and rodents: Review article. Vet. Pathol. 21(2): 238-246.

Anosa V.O. \& Kaneko J.J. 1984. Pathogenesis of Trypanosoma brucei infection in deer mice (Peromyscus maniculatus). Light and electron microscopic study of testicular lesions. Vet. Pathol. 21(2):238-246.

Anosa V.O. 1988. Haematological and biochemical changes in human and animal trypanosomosis. Parts I and II. Revue Élevage Méd. Vét. Pays Tropicaux 41:65-78, 151-164.

Apted P.I.C. 1970. Clinical manifestations and diagnosis os sleeping sickness, p.661-683. In: Mulligan E.W. \& Potts W.H. (Ed.), The African Trypanosomiasis. Allen and Unwin, London.

Batista J.S., Bezerra F.S.B., Lira R.A., Carvalho J.R.G., Rosado Neto A.M., Petri A.A. \& Teixeira M.M.G. 2008. Aspectos clínicos, epidemiológicos e patológicos da infecção natural em bovinos por Trypanosoma vivax na Paraíba. Pesq. Vet. Bras. 28(1):63-69.

Batista J.S., Riet-Correa F., Barbosa R.C. \& Guerra J.L. 2006. Infecção experimental por Trypanosoma vivax em ovinos. Pesq. Vet. Bras. 26(1):31-37.

Batista J.S., Riet-Correa F., Teixeira M.M.G., Madruga C.R., Simões S.D.V. \& Maia T.F. 2007. Trypanosomiasis by Trypanosoma vivax in cattle in the Brazilian semiarid: Description of an outbreak and lesions in the nervous system. Vet. Parasitol. 143:174-181.

Bezerra F.S.C., Batista J.S., Sousa F.D.N., Lira R.A., Carvalho J.R.G. \& Godoi R.M.I. 2006. Aspectos clínicos e reprodutivos da infecção natural por Trypanosoma vivax em bovinos leiteiros no Alto Sertão da Paraíba. Anais IV Congr. Nordestino de Produção Animal, Petrolina, p.1135-1137.
Boly H., Humblot P., Tillet Y. \& Thibier M. 1994. Effects of Trypanosoma congolense infection on the pituitary gland of Baoule bulls: Immunohistochemistry of $\mathrm{LH}$ and $\mathrm{FSH}$-secreting cells and response of plasma $\mathrm{LH}$ and testosterone to combined dexamethasone and $\mathrm{GnRH}$ treatment. J. Reprod. Fertility 100:157-162.

Brener Z. 1961. Contribuição ao estudo da terapêutica experimental da doença de Chagas. Tese de Livre Docência, UFMG, Belo Horizonte. 90p.

Cabrine-Santos M. 2000. Estudo da fase crônica da infecção e reinfecção por Trypanosoma cruzi no hamster: avaliação e caracterização da cepa VIC por métodos parasitológicos, imuno-histoquímicos e de biologia molecular. Dissertação de Mestrado em Patologia, Faculdade de Medicina do Triângulo Mineiro, Universidade Federal do Triângulo Mineiro, Uberaba, MG. 144p.

Cabrine-Santos M., Santos V.M., Lima M.A., Abreu M.E.A., Lages-Silva E. \& Ramírez L.E. 2003. Genitourinary changes in hamsters infected and reinfected with Trypanosoma cruzi. Mem. Inst. Oswaldo Cruz 98(4):523-528.

Clementino I.J., Alves C.J., Azevedo S.S., Paulin L.M. \& Medeiros K.A. 2007. Inquérito soro-epidemiológico e fatores de risco associados à infecção por Brucella ovis em carneiros deslanados do semi-árido da Paraíba. Pesq. Vet. Bras. 27(4):137-143.

Dávila A.M.R. \& Silva R.A.M.S. 2000. Animal Trypanosomiasis in South America: Current status, partnership, and information technology. Annals N.Y. Acad. Sci. 916:199-212.

Dibarrat J.A.D., Aparício E.D., Reynoso B.A., Gutiérrez V.R.T. \& Pérez J.T. 2006. Inducción experimental de epididimitis en ovinos por inoculación intrauretral com Actinobacillus seminis: estúdio bacteriológico, serológico e histopatológico. Técnica Pecuaria en México 44(2):127-267.

Ferreira Neto J.M., Viana E.S. \& Magalhães L.M. 1981. Patologia Clínica Veterinária. Rabelo, Belo Horizonte. 279p.

Friedman R., Bullard J.F. \& Johnson L.E. 1991. The effects of increased testicular temperature on spermatogenesis in the stallion. J. Reprod. Fertility 44:127-134.

Gardiner P.R. 1989. Recent studies of the biology of Trypanosoma vivax. Adv. Parasitol. 28:229-317.

Gomes M.J.P. 1991. Isolamento e identificação de Chlamydia psittaci de reprodutores bovinos com adenite vesicular, no Estado do Rio Grande do Sul. Dissertação de Mestrado em Microbiologia Veterinária, Curso de Pós-Graduação em Microbiologia Veterinária, Universidade Federal Rural do Rio de Janeiro, Itaguaí, RJ. 95p.

Holmes P.H. 1997. Pathophysiology of parasitic infections. Parasitology 94:829-851.

Ikede B.O. \& Losos G.J. 1975. Pathogenesis of T. brucei infection in sheep, hypophyseal and other endocrine lesions. J. Comp. Pathol. 85:37-44.

Kimeto B.A., Mugera G.M. \& Nyaga P.N. 1990. Haemorrhagic pancarditis in cattle infected with Trypanosoma vivax. Vet. Parasitol. 34:295-301.

Linhares G.F.C., Dias Filho F.C., Fernandes P.R. \& Duarte S.C. 2006.Tripanossomíase em bovinos no município de Formoso do Araguaia, Tocantins: relato de caso. Ciênc. Anim. Bras. 7(4):455-460.

Losos G.J. 1986. Infectious Tropical Diseases of Domestic Animals. Longman Scientific and Technical, Harlow Essex. 938p.

Manterola L., Tejero-Garcés A., Ficapal A., Shopayeva G., Blasco J.M., Marin C.M. \& López-Goñi J. 2003. Evaluation of a PCR test for the diagnosis of Brucella ovis infection in semen samples from rams. Vet. Microbiol. 92:65-72.

Masake R.A. 1980. The pathogenesis of infection with Trypanosoma vivax in goats and cattle. Vet. Rec. 13:551-557.

McEntee K. 1990. Reproductive pathology in domestic mammals. Academic Press, San Diego. 401p.

Mutayoba B.M., Eckersall P.D., Jeffcoate L.A., Cestnik V. \& Holmes P.H. 1994. Effects of Trypanosoma congolense infection in rams on 
the pulsatile secretion of testosterone and response to injection of GnRH. J. Reprod. Fertility 102:325-326.

Nascimento E.F. \& Santos R.L. 2003. Patologia da Reprodução dos Animais Domésticos. $2^{\mathrm{a}}$ ed. Guanabara Koogan, Rio de Janeiro. 137p.

Ngeranwa J.J.N., Mutiga E.R., Agumbah G.J.O., Gathumbi P.K. \& Munyua W.K. 1991. The effects of experimental Trypanosoma (trypanosozoon) (brucei) evansi infection on the fertility of male goats. Vet. Res. Commun. 15(4):301-308.

Paiva F., Lemos R.A.A., Nakazato L., Mori A.E., Brum K.E. \& Bernardo K.C.A. 2000. Trypanosoma vivax em bovinos no Pantanal do Mato Grosso do Sul, Brasil: I. Acompanhamento laboratorial e anatomopatológico de rebanhos infectados. Revta Bras. Parasitol. Vet. 9(2):135141.

Pellín C.E.S., González F.A.G., Baldizán G. \& Liñarez F.F.M. 2003. Comportamiento parasitológico, clínico y hematológico em ovinos infectados experimentalmente con un aislado venezolano de Trypanosoma vivax. Vet. Tropical 28(1):79-92.

Rio Tinto J.J.M., Alves G.E.S., Santos R.L., Faleiros R.R., Marques Júnior A.P. \& Melo E.G. 2004. Fechamento parcial do anel inguinal externo em eqüinos: avaliação pós-operatória e influência na morfologia testicular. Arq. Bras. Med. Vet. Zootec. 56(6):715-722.

Robles C.A., Urcullú J., Uzal F.A. \& Merlo R. 1990. Primer diagnóstico en Patagonia de orquioepididimitis en carneros por bacilos pleomorficos gram negativos. Vet. Argent. 7(67):453-455.

SAS 1999. User's Guide. 6th ed. Statistical Analysis System, Cary. 956p.

Sekoni V.O., Njoku C.O., Kumi-Diaka J. \& Saror D.I. 1990. Pathological changes in male genitalia of cattle infected with Trypanosoma vivax and Trypanosoma congolense. Brit. Vet. J. 146:175-180.

Sekoni V.O., Rekwot P.I. \& Bawa E.K. 2004. Effects of Trypanosoma vivax and Trypanosoma congolense infections on the reaction time and semen characteristics of Zebu (Bunaji) x Friesian crossbred bulls. Theriogenology 61:55-62.

Setchell B.P. 1998. The parkes lecture heat and the testis. J. Reprod. Fertility 114:174-194.

Silva R.A.M.S., Pellegrin A.O., Ramirez E.S.S.L.L. \& Dávila A.M.R. 2004 Abortos por Trypanosoma vivax no Pantanal Mato-Grossense e Bolívia. Documentos 75, Embrapa Pantanal, Corumbá. 30p.

Silva R.A.M.S., Silva J.A., Schneider R.C., Freitas J., Mesquita D., Mesquita T., Ramirez L., Dávila A.M.R. \& Pereira M.E.B. 1996. Outbreak of trypanosomiasis due to Trypanosoma vivax (Ziemann, $1905)$ in bovines of the Pantanal, Brazil. Mem. Inst. Oswaldo Cruz 91(5):561-562.

Shaw J.J. \& Lainson R. 1972. Trypanosoma vivax in Brazil. Annals Trop. Med. Parasitol. 66(1):25-33.

Valera Z., Parra O., Alvarado M., Barboza G., Escalona F. \& Ramírez R. 2005. Efecto de la infección experimental com Trypanosoma vivax sobre parámetros hematológicos em ovinos. Revta Cient., Maracaibo, 15(5):412-420.

Ventura R.M., Paiva F., Silva R.A.M.S., Takeda G.F., Buck G.A. \& Teixeira M.M.G. 2001. Trypanosoma vivax: characterization of the spliced-leader gene for a Brazilian stock and species-specific detection by PCR amplification of an intergenic space sequence. Exp. Parasitol. 99:37-48.

Walker R.L., Lea Master B.R., Stellflug J.N. \& Biberstein E.L. 1986. Association of age of ram with distribution of epididymal lesions and etiologic agent. Journal of the Am. Vet. Med. Assoc. 188:393-396.

Whitelaw D.D., Gardiner P.R. \& Murray M. 1988. Extravascular foci of Trypanosoma vivax in goats: The central nervous system and aqueous humor of the eye as potential sources of relapse infections after chemotherapy. Parasitology 97:51-61. 